\title{
Geographical Indications of Origin: When GIs Become Commodities, All Gloves Come Off
}

\author{
Anselm Kamperman Sanders
}

Published online: 29 September 2015

(C) Max Planck Institute for Innovation and Competition, Munich 2015

There is not a single intellectual property right that has so consistently led to heated debates in international trade other than geographical indications of origin (GIs). The combined interaction of human ingenuity, methods of production, and geographical location apparently creates an explosive mix when holders of a GI right try to assert a GI away from the immediate vicinity of the location that the indication denotes or the product bearing it is tied to.

Human knowledge, language and culture have been ported to other locations as a result of human interaction, immigration and even exile. This may result in the production of comparable products through use of comparable methods in new locations, while retaining or referencing former localities or the old home country. If the original product has obtained notoriety, naming the new product by the original geographical indication may be tempting from a commercial perspective, but a sense of belonging, roots or personal identity may also lead to the (referential) use of a geographical location, even though the production of a product has moved elsewhere. New-world nations, most notably the North-Americas and Australia, have consistently rejected the notion of a multilateral register for geographical indications that is dominated by European claims. It comes as no surprise then that in the context of the negotiation mandate contained in TRIPS Article 23, no significant progress has been made or can be expected. WTO negotiations are after

\footnotetext{
A. Kamperman Sanders $(\bowtie)$

Professor of Intellectual Property Law, Director of the Advanced Masters Intellectual Property Law and Knowledge Management (IPKM LL.M/MSc), and Academic Director of the Institute for Globalization and International Regulation (IGIR) at Maastricht University; Academic Co-director of the Annual Intellectual Property Law School and IP Seminar of the Institute for European Studies of Macau (IEEM), (Macau SAR, China); Adjunct Professor at Jinan University Law School,

(Guangzhou, China); member of the European Commission expert group on development and implications of patent law in the field of biotechnology and genetic engineering

Maastricht, The Netherlands

e-mail: a.kampermansanders@maastrichtuniversity.nl
} 
all part of a single undertaking, so unless there is a deal on all issues of trade, there is no deal at all.

In an act of forum shifting from the WTO to WIPO, however, the Diplomatic Conference for the Adoption of a New Act of the Lisbon Agreement for the Protection of Appellations of Origin and Their International Registration reached consensus on a new act on May 21, 2015. This Geneva Act updates the Lisbon Agreement stemming originally from 1958 to be compatible with current international agreements, such as TRIPS. At first glance the innovation of the Geneva Act is that it permits the accession to the Lisbon Agreement of certain intergovernmental organizations, most notably the European Union. Also it widens the scope of the agreement enabling all beneficiaries of geographical indications, not only appellations of origin in the classical sense, to file an application for international registration that is administered by WIPO.

The Geneva Act is presented by WIPO as a multilateral agreement, but detractors are already calling foul play. ${ }^{1}$ A U.S. statement on the adoption of the Geneva Act of the Lisbon Agreement speaks of the "strip[ping of] 160 WIPO members of meaningful participation rights". To shed crocodile tears after having been able as a non-member to exercise considerable influence over an international agreement is rather in keeping with the nature of the USA's engagement; claim a place at the table as an observer and exert influence without taking responsibility for the outcome.

The statement rings hollow as the WIPO process is far more inclusive and multilateral than, for example, the US-led Anti-Counterfeiting Trade Agreement (ACTA) before it. The WIPO process is also much more transparent and it is wellreported that the USA was represented by a rather large delegation during the preparatory committee meetings and the diplomatic conference. What's more, it had a sizable influence on the wording of the provisions dealing with generic terms and the interface between geographical indications and trade marks. These provisions dealing with prior trade mark rights and invalidation furthermore contain the real innovation in the Geneva Act of the Lisbon Agreement.

The statements made by the U.S. on the Geneva Act must therefore also be seen in light of the need to placate domestic audiences. The American Consortium for Common Food Names (CCFN) and the U.S. Diary Export Council (USDEC) represent a significant portion of the U.S. agricultural industry, and they have been very vociferous in their rejection of protection of (European) geographical indications. The rhetoric surrounding the revised Lisbon Agreement is therefore tame compared to the diatribe surrounding current negotiations between the EU and the USA on the Transatlantic Trade and Investment Partnership Agreement (TTIP).

For the European Union, the protection of its GIs in and outside of Europe is a very relevant economic issue, as the value of GI products in 2010 was estimated at $€ 54.3$ billion, of which the sale of wines account for more than half. ${ }^{2}$ The European Union is therefore relentlessly placing the protection of geographical indications at

\footnotetext{
${ }^{1}$ https://geneva.usmission.gov/2015/05/20/u-s-statement-on-the-adoption-of-the-geneva-act-of-the-lisbonagreement/.

${ }^{2}$ See the European Study "Value of production of agricultural products and foodstuffs, wines, aromatised wines and spirits protected by a geographical indication (GI)" (available at: http://ec.europa. eu/agriculture/external-studies/value-gi_en.htm).
} 
the heart of its intellectual property chapters in free trade and association agreements. The annexes to the EU-Korea, EU-Singapore FTAs, and the recent Canada EU Trade Agreement (CETA) all contain listings of GIs that are to be protected in the partner countries as part of the trade deal.

The comprehensive inclusion of geographical indications in CETA can be considered quite a success for the EU, as Canada not only protects geographical indicators as trade marks only, but also because it has, as an immigrant nation, traditionally been resistant to European claims to geographical indications. Despite its acceptance of the EU position on the protection of GIs, Canada made express reservations in CETA. These look rather arbitrary and cover "Valencia oranges, Black Forest ham (but not Schwarzwaelder Schinken), Tiroler bacon, Parmesan, Bavarian beer, Munich beer, and Noix de Grenoble". It furthermore limited the scope of protection for certain GIs, in that epithets such as "kind", "type", "style" and "imitation" remain available for use in relation to cheeses such as "Asiago, feta, fontina, Gorgonzola and Munster", or that certain terms or component parts of GIs remain freely available for use by third parties. Whereas "Gouda Holland" is thus protected, the term "Gouda" as such can be freely used. Still, it is a very pragmatic solution that is held out by the EU as a template for TTIP negotiations despite CCFN's forceful rejection. As a result, the issue of GI protection is not only likely to remain just as controversial as investor-state dispute settlement or genetically modified organisms, but also fundamentally industry-interest driven, rather than objectively informed by the interests of consumers.

Conversely, for the purpose of cross-retaliation in countervailing measures against the EU resulting from WTO disputes, import measures affecting the import of GI products seems to be the preferred choice when it comes to singling out a European industry that is perceived to be politically sensitive and having sufficient lobbying power to ensure compliance with WTO rulings. In 1999 the US (and Canada) retaliated in respect of Roquefort cheese, Dijon mustard and other agricultural products as part of its retaliatory tariff suspension targeting US $\$ 100$ million worth of EU imports resulting from the EC-Hormones ${ }^{3}$ case. The UK was exempted from this retaliatory action as it favoured a lifting of the EU's ban on the import of hormone beef from the USA. The dispute is still on-going. ${ }^{4}$ Similarly, Ecuador, in response to the EC - Bananas III (Ecuador) case, ${ }^{5}$ targeted geographical indications, most notably French wines and Scottish whisky, in its retaliatory measures against the EU.

Meanwhile CCFN's mission to gain the widest possible international support for its position may be nefarious from the perspective of GI right holders, but a critical stance against claims to GIs is not always without merit. There are several geographical indications claimed that seem to favour the geopolitical

\footnotetext{
${ }^{3}$ EC - Hormones; Appellate Body Report, EC Measures Concerning Meat and Meat Products (Hormones), WT/DS26/AB/R, WT/DS48/AB/R, adopted 13 February 1998, DSR 1998:I, p. 135.

4 See R. Johnson, "The U.S.-EU Beef Hormone Dispute”, (2015, Washington, Congressional Research Service, R40449) (available on 02/04/2015 at: https://www.fas.org/sgp/crs/row/R40449.pdf).

5 EC-Bananas III (Ecuador); Panel Report, European Communities - Regime for the Importation, Sale and Distribution of Bananas, Complaint by Ecuador, WT/DS27/R/ECU, adopted 25 September 1997, as modified by Appellate Body Report WT/DS27/AB/R, DSR 1997:III, p. 1085.
} 
power of vested European industrial interests, irrespective of their dubious claims or historical revisionism used to justify these claims. A case in point is the sudden enlargement in 2009 of the area of production for "Italian Prosecco". The production of this sparkling wine has been traditionally confined to the Veneto Region around Venice and was suddenly "strategically" expanded to include the town of Prosecco, located in the Friuli-Venezia Giulia Region near Trieste and the Slovenian border. This is the place where the prosecco grape variety is believed to have originated. Upon accession to the EU in 2013, Croatia found that its sweet Prošek desert wine, which is different from Italian Prosecco in all aspects of methods of production and grapes used, could no longer coexist in the EU with Italian Prosecco. The reason for the inclusion of the town of Prosecco, of which the Slovenian name is Prosek, in the Italian GI terroir became abundantly clear. It deprives Croatia of a veritable challenge to the Italian Prosecco GI for having no link whatsoever to the actual geographical location bearing that name.

The irony of the entire saga is that after numerous armed conflicts between the Republic of Venice and Trieste, the citizens of Trieste successfully petitioned Leopold III of Habsburg for protection in 1382. The Free Imperial City of Trieste and its surrounding Küstenland (coastal lands) were only captured from the Austrian-Hungarian Empire by the Italian army in 1918 and were formally annexed by the state of Italy in 1920 by the treaty of Rapallo. After the Second World War, Tito captured Istria (now shared by Croatia, Slovenia and Italy) and a large part of Friuli-Venezia Giulia. In 1947, Trieste (including Prosecco with its strategically important railway station) was declared an independent city-state under UN protection and the formal division of territories between Yugoslavia and Italy was concluded only in 1975 in the Treaty of Osimo. Whereas Italy's current territorial claim to Trieste and the town of Prosecco is legitimate, Veneto's wine producers have relatively recently been allowed to usurp a territory and name that has no historical connection with its sparkling Prosecco other than that wine made of prosecco grapes was once traded into Venice from elsewhere, and that later its local product used this grape variety to produce a sparkling. As result, the Veneto Prosecco GI producers have rewritten history in an attempt to safeguard their economic interests to the detriment of a product that has been legitimately produced in another EU Member State for over 2000 years. It is almost as if after centuries the Republic of Venice has won its war.

The CCFN website opens with a quote from a Wisconsin Member of the United States Congress: “... We're going to keep making gouda in Wisconsin. And feta, and cheddar, and everything else. So, it is extremely important that we do not allow these countries ... to use these kinds of improper barriers to block U.S. dairy exports." The American stance can be attributed still to the taxes imposed by King George III and the Boston Tea Party, but to a European many geographical indications are far from generic. To this author, himself a Dutchman, "Gouda from Wisconsin" sounds like a cheap knockoff worthy of having a tea party over.

It just goes to show that GIs may be presented as great expressions of collective human tradition, history, culture and knowledge about natural resources from a certain locality. It certainly explains why GIs bring about a deep personal 
connection, but also provoke strong emotional reactions. When ultimately GIs become commodities all gloves come off and everyone becomes very territorial despite a globalising world. 